\title{
G Antigen 6
}

National Cancer Institute

\section{Source}

National Cancer Institute. G Antigen 6. NCI Thesaurus. Code C104477.

G antigen 6 (117 aa, $\sim 13 \mathrm{kDa}$ ) is encoded by the human GAGE6 gene. This protein may be involved in tumor malignancy. 